\title{
Islamic Philosophy and Politics (The Experience of Interpretation)
}

\author{
Viktor Vasilievich Zheltov
}

Maxim Viktorovich Zheltov

Sergey Vladimirovich Birukov

Kemerovo State University, Russian Federation, 650043, Kemerovo, Krasnaya Street,6

Doi:10.5901/mjss.2015.v6n6s1p537

\begin{abstract}
The article highlights the historical background of the diversity of Islam related to the influence of pre-Islamic culture in different countries, as well as the impact of socio-economic cooperation of Islamic countries with the West. It analytically reveals the phenomenon of Islamization of ancient Greek philosophy as a phenomenon of its adaptation to the realities of the Islamic world showing opportunities of philosophy as a science in the Islamic world, and the role of the Qur'an in the development of philosophy and politics in the Muslim countries. The article touches upon the questions of the role of Islam in the Muslim countries ' politics, trans-prospects and building democracy in the Arab world analyzing "The Arab Spring" political legacy and future perspectives of its influence.
\end{abstract}

Keywords: ancient Greek philosophy, Islamic philosophy, Islam, Moslem world, the Koran, Revelation, politics, democracy, pluralism

\section{Introduction}

As a rule, the philosophical and political literature says about Islam, as they say in general terms, i.e. as a single doctrine. Meanwhile, there is no single Islam. Political scientists and religious-WIDE Islamic thinkers rightly speak of the existence of: Sunni-ray and Shia Islam; Islam, which are practiced in Riyadh (Saudi Arabia) and Bamako (Mali); version of Islam in Morocco and Indonesia. A thorough analysis....(Clifford Geertz (1926-2006)).

According to Clifford Geertz an imprint of the pre-Islamic culture of the country is imposed on one or another specific form of Islam in each country (Cf. Geerz C., 1968). This position is confirmed by Clifford Geertz, particularly in Turkey and Iran. "In order to understand the specific religious attitude to politics in Turkey, - said S. Vaner (Vaner Semih $(1945$ - 2008)) - is necessary, first of all, to emphasize the original vitality of Central Asia: the elements of shamanism (Shamanism is a previous form of religion based on the belief that shaman communicate with spirits when being in trance), Buddhism and Manichaeism (Manichaeism is a religious practice in the late antiquity created by a Persian prophet Mani or Manes), which were supported by the Turks in Central Asia after the adoption of the two nations of Islam, and these beliefs people carried with them through the years in different forms in the Ottoman Empire "(Vaner S., 2008).

The same can be said for logic of statements of Shia Islam in Iran, where was confirmed the peculiar relationship between the imams of the XII century and the figure of the Saviour of old Zoroastrian Persia (Zoroastrianism is a form of religion in the ancient ages and early Medieval ages in the Middle Asia, Persia, Afghanistan, Azerbaijan and some countries in the Near and Middle East), (Corbin H.1971, 1985).

It can be argued that Islam is undergoing significant changes under the influence existed in one country or another form of religious belief. Here is evidence of M. Arkoun (Daryush Shayegan, 1989) on Kabylia (Mohammed Arkoun (b. 1928)): "It is necessary to recall that in Kabylia remained mountain ranges, olive trees, sources, which are places of worship of paganism, there is, in other words," animistic (Kabyle is a historic and geographic region in the northern part of Algeria)"religion in Kabylia, and I have personally seen with my mother, which I was accompanied by to one of the sources located in the mountains, in order to worship the mind of those who live at the source, and to keep oneself in good health "(Animism (from Latin anima, animus - «soul» and «spirit») is a belief in the existence of soul, spirits and spirituality of the nature).

In general, the reality of the Muslim world is not so correct origins of Islam, as it wrote Weber, when he spoke of "the invasion of the Persian Sufism of Indian origin and formation of the order of dervishes (Arcoun M. 2012), who are experiencing a strong influence on the Indians to the present day." In addition, Weber argued that "the petty bourgeoisie is largely carrier of religiosity of the dervishes, which is widespread [the Islamic world] and which gaining strength, 
superior in the influence the official Church" (Dervish (Pers. a beggar) is the Islamic analogue of a monk and ascetic, follower of Sufism).

Another source of well-known diversity of Islamic countries is the difference in their relations with the West over the past two centuries. For example, in Turkey there was an attempt of substantial Westernization of the country, carried out by Ataturk (Weber M.,1995), while Saudi Arabia, for example, has almost no exposure with the process of Westernization of the country (Kemal Atatürk (1881 - 1938)).

\section{The Philosophy of the Arab World and the Islamization of Greek Philosophy}

From the first centuries of Islam, many of its spiritual conquests, and especially philosophy, were the result of a meeting with the legacy of the ancient Greeks. Inspired by the thought of the Greeks, Islamic thinkers faced with intellectual heritage other than the Quran. This especially applies to everything that is associated with the policy as the main component of the Greek philosophical thought (Iribarne Ph.d., 2013).

The philosophy of the Arab world is not just addressed to the heritage of the ancient Greeks, it Islamized Greek philosophy. Islamization touched primarily the object of philosophical thought. What attracts the attention of a philosopher, rooted, as we know, in the idea of unity and omnipotence of God and all that is associated with it - such is the purpose of divine knowledge or concept of creation (Cf. Vernant J.-P. 1962).

Greek heritage is twofold. It contains the contradiction between agora (Meryem Sebti. 2007) and belief in miracles. This contradiction, in the figurative remark of J.-P. Vernal (Agora - a central square in ancient Greek city-states, the place of all community rallies which also were called "agoras"), as if slips "between the spirit of the secrets inherent to sects, and publicity of controversial debates, which are characteristic for political activity" (Jean Pierre Vernant (1914 - 2007)) .

"In accordance with the environment, time trends, we see - writes J.-P. Vernal - how the Pythagorean sect in ancient Greece in the VI century turns into a closed fraternity and refuse the written evidence of their purely esoteric doctrine. This brotherhood could just as it will be made by the Sophists, be fully integrated into public life, presenting itself as an organization, engaged in preparations for the exercise of power in the city and offering every citizen paid lessons "(Jean Pierre Vernant (1914 - 2007)).

Islamic philosophy is not without the influence of the ancient Greeks interested in the life of the policy, but remains faithful to its own vision, according to which the true and the good come from above: "The best city - said K. Jamba (Vernant J.-P. 1962) - is not one in which there have been discussions but one in which the maximum power solutions specifies a maximum true knowledge "(Jambet Christian (b. 1949)).

This approach coincides with the ideas of Plato, expressed in the "State". This very popular today book of the ancient Greek philosopher runs as follows:

"Until the states will not be reigned by philosophers, or the so-called current kings and lords will not nobly and thoroughly philosophize and it merges together - government and philosophy, and until those people - and there are many - who now aspire either separately either to power or to philosophy will not be obligatory excluded, so long, my dear Glaucon, states will not get rid of the evil, and the state that we just described verbally will not be possible for the human race and will not see the sunshine "(Jambet Ch., 2011).

\section{And further:}

"... Just philosophers should rule, and when it will become clear, we can begin to defend and prove that some people are by their very nature ought to be philosophers and rulers of the state, and all others need not to be engaged in this, but follow those who lead "(Jambet Ch., 2011).

In the Islamic context one can say with all definiteness that only God is the true sovereign, "Man becomes the more clever and fulfils better control - believes K. Jamba - the more he obeys his Lord." And like Plato, Islamic philosophers do not believe in the virtue of public debate (Jambet Christian (b. 1949)). They are advocates of providential (http://grani.roerich.com/plato/txt/republic05.htm) rule. direction?

Let us ask ourselves, after the Islamic thinkers: by means of what intermediaries followed the providential

Starting from Al-Farabi (Providentialism (from Latin providentia - providence) is a historic and philosophic method of researching the historic events from the point that Providence is present in such occurrences and that God has the beforehand plan of saving people) and further to Averroes (Al-Farabi ( 872 - between Dec. 14, 950 and Jan. 12, 951)), preference is given to theological-political authority (Jambet Christian (b. 1949)). Thus, according to Avicenna, 
"Revelation is a word that extends, and its source is the Prophet. He provides the royal power, which is the power received by the Prophet, as if the power for Him is an expression of angelic knowledge of His mind "(Jambet Christian (b. 1949)).

K. Jamba concludes: "In Islam, the mind cannot be identified with what the concept expresses since Descartes in the West. We are talking about the divine mind, caused in man by force of his intellect, the force that comes from God by means of an intelligent agent, the same archangel Gabriel (Averroes (1126 - 1198)). As a result, this means that political philosophy in Islam cannot be a liberal philosophy ... The people of the community, for which political authority is created, have need for master who is invisible, but who possesses superhuman qualities, a man from among the seniors, or divine man, who was human master, the Divine caliph in this world "(Jambet Christian (b. 1949)).

I must say that by the opinion generally accepted in the scientific community the legacy of Plato played a major role in the development of Islamic philosophy. However, this heritage was not of a hegemonic nature. As it is known, Averroes, who was chiefly a follower of Aristotle rather than Plato, defended in his work the idea of autonomous reason. And it turns out that his contribution to Islamic philosophy can be seen from the position of countertendency to the subsequent Islamic philosophy in Iran. For example Averroes, being a Muslim thinker, who had a lot of views in common with Western philosophy, demonstrates in his writings that Islamic philosophy is a very specific science (Kemal Atatürk (1881 - 1938)).

Its specificity is reflected, in particular, in the fact that in Islamic philosophy Revelation plays a special role (Gabriel - an archangel mentioned in the Old and New Testament and Quran). Thus, Averroes in his work speaks from the position of defender of philosophy as "milk sister" of Revelation, involving "a rational analysis that leads to true knowledge of God" (Revelation - declaration of God's will according to the Christian dogmas). Moreover, according to Averroes, Quranic revelation is the bearer of truth. "The ultimate goal of Revelation - claimed Averroes - is this: learn the true science and true praxis." According to Averroes the genuine science is "the knowledge of God - let Him be blessed and exalted - and a set of manifestations of being what they are - especially the most divine of them - and the knowledge of the commandments and torment in the afterlife." Genuine praxis is "to fulfill actions that ensure observance of the commandments, and the avoidance of actions that lead to torture" (Revelation - declaration of God's will according to the Christian dogmas).

Mind, says Averroes, in any case can not contradict the truth of Revelation. "We, the Muslims, know from reliable science that studies [of objective reality] with demonstrations, does not lead to contradictions with the teaching that comes from Sacred Text: because truth cannot come into conflict with truth, but is in agreement with it and testifies in its favor "(Revelation - declaration of God's will according to the Christian dogmas).

According to Averroes, evidence obtained as a result of the study, have a compulsory character: "The agreement with something influenced by evidence obtained with mind - is not free, but a compulsory act, i.e., it is not in our power to agree or disagree [with evidence], just as in our power is a fact associated [with our decision] to be in a standing position or not "(Revelation - declaration of God`s will according to the Christian dogmas) (Emphasis added. - V. J., M.J).

In accordance with the logic of Islamic philosophy, the question arises: in such situation, which we are talking about, could we blame those who retreat from the faith and are at odds with the Quran, for instance, in their scientific views? And the question arises: is there within the Islamic philosophy any possibility for the existence any other legitimate opinion, which would be inconsistent with the provisions of the faith?

In Quran and Islam in general, the possibility of such opinion is not excluded. But the indicated legitimate opinion stays initially in limited boundaries.

"Practical religious issues" - requirements that determine the mode of existence, and especially those that are associated with the life of the city - are excluded from the discussion. According to Averroes, Quranic revelation brings credibility, thanks to the wording that should be taken literally. And agreement with the meaning, in essence, brings faith: "It is sufficient to reach consensus, which is to spread this doctrinal position without having to talk about the differences with this position," (Revelation - declaration of God's will according to the Christian dogmas). This means that a variety of interpretations of Islamic philosophy is practically impossible.

And what to do with the theory which needs to be discussed and compared, and the different points of view and approaches in the search for truth? This truly scientific approach has the right to life just outside of the issues that have a definite answer in Scripture. However, the theoretical study of such issues is the destiny only of qualified scientists.

Putting forward the thesis of freedom of interpretation and discussion of theoretical issues, Averroes relied on the Quran (Sura 3), "He - the One who has sent down the Book to you; it has a poetry, arranged in order that - the mother of the book; and others - are similar in meaning. But those in whose hearts evasion - they follow what it resembles, soliciting confusion and interpretation of soliciting. No one knows its interpretation except Allah. And solid in knowledge say: "We believe in Him; everything - from our Lord. "They remember only the owners of the mind "(Averroès., 1996). 
Confirming their agreement with the statement of Quran, Averroes claims that the approach of scientists in science, in fact, does not have any specificity in the study of reality, which differs from the approach of scholars from among the faithful Muslims and in both cases it is based on Faith in the Lord (Revelation - declaration of God's will according to the Christian dogmas).

This approach has political continuation: ordinary people are thinking outside the field of academics. This means that the political leaders of the Muslims, by Averroes, should prohibit scientific books for the Muslims, who are not related to this science (Revelation - declaration of God's will according to the Christian dogmas). This political position brings to life the desire of the Muslim authorities to avoid unnecessary debate that can produce division of the Muslim community, and even lead to violence in society.

\section{Islamic Philosophy and Political Issues}

Combination of the ancient Greeks heritage with Islam took a selective path. Islamic thinkers chose only the heritage issues that fitted in the Quran concept. Plato's image of the governor-philosopher is not strange to imam-philosopher, political leader of the Muslims, embodies the union of religion and philosophy. However, all that discussions on the public areas of ancient Greece don't fit into the idea of politics in the Islamic world.

It could be sufficient to apply to the heritage of Aristotle. Regarding city life, he describes in his "Politics" the multiplicity of citizens' opinions as the condition for the success government: "It is preferable that the supreme power belongs to the majority rather than to the minority, at least composed of the best leaders and therefore could be obviously considered as the satisfactory solution to the issue and contains some excuse and perhaps even the truth. It may occur that the majority composed with individuals could be inefficient but joint together could be better than that minority just as lunches are better than clubbing dinner hosted by the means of a single person. As the majority includes a lot of people, it is possible that there are pure virtue and prudence in each of them, taken separately; and when these people come together it seems as if we got a real individual of these many with lots of hands, legs and perceptions and the same applies to the temper and understanding. That's why the majority better estimate musical and poetic works: some view them from the one side, the other - from the other, and all together they view the problem overall...however...if all this people mass is not entirely devoid of the inherent dignity of the freeborn man, than each individual is the worst judge, and all together are not the best ones, or at least not the worse judges". (Quran, Moscow, 1963).

Aristotle reasonably supports the perspective of the need for realistic accounting in policies of human sentiments and passions, as well as the need for a policy of so-called lesser evil, that takes into account the effects of the famous people mediocrity.

According to F. d'Iribarren it directly relates to the reason, but practical reason, which takes into account not only the expectations of Light from above, but also the common experience of ordinary people. This means that Aristotle is interested not only in the views of scholars and Revealed Truth, but also in the position of ordinary people in politics. This is not a weakness of the thinker, but - his strength (Kemal Atatürk (1881 - 1938)).

Aristotle writes:

"There are three parts in every government: very wealthy people, very poor and the third part of those who stands in the middle. Since moderation and the middle position are the best issues according to the received opinion, then obviously the average income of all the benefits is the best good. Thus it could seem easier to obey to reasons of conscience; but on the contrary, it is difficult to follow these arguments for an advanced, strong, noble, rich person or vice verse for a poor, weak, socially humble person. The people of the second part often become evildoers and bastards". (Quran, Moscow, 1963).

Islam was initially marked by the original mentality connecting together the concept of truth, reason, good life and debate. The truth comes from above.

The reason is the ability to perceive what is given from above and the process of perception of this. The good life is the result of model accordance of the great writing. The debate is the tool of cognition the truth but not the factor of community destruction.

In time this space is not changing. And this is the core for one of the complexity causes of social and political development of the Muslim world. Adonis, the famous Arab thinker writes about it with great concern (Aristotle. Writings in 4 volumes, Moscow, 1984): "There have been lots of experiments in lives of Arabians concerning the implementation of all forms of government, but nothing has changed in society, nothing of what had to be changed. Even the revolution experiment has only led to disastrous results" (Adonis (the real name Ali Ahmad Said Asbar, b. 1930) , 2014).

Such a negative assessment of social development in the Arabian world, including the transformations that marked 
the political life of the Muslim countries under the influence of the Arab Spring, perhaps, have the right to live, if consider that during several centuries Islamic civilization have produced political regimes that are far from democratic ones (Aoun S., 2013), but could be easily identified more as authoritarian, dictatorial and even tyrannical.

\section{Islam and Democracy}

By real democracy parameters the Muslim countries are placed much lower of the top ones. For example, in 2011 the authoritative English magazine «The Economist» on the basis of 60 criteria based on five categories (the electoral process and pluralism, civil liberties, functioning of government, political participation and political culture) could not apply the determinant of "democratic" to any Muslim country. Only two countries (Mali and Malaysia) came into the category of "imperfect democracy", whereas all the other Muslim countries were classified as "hybrid regime" or "authoritarian regime". (Kemal Atatürk (1881 - 1938)).

And there are so called philosophical reasons. They suppose that in the Muslim world, Islamic vision of democracy and the power is fundamentally different from current interpretations of these concepts in Europe. Against the background of the Arabian Spring and those philosophical issues that the latter has set to the Arabian religious leaders, philosophers and politicians there were heard statements that Islam does not agree well with democracy because of its theocentricism implying that the sovereignty belongs to God, while democracy is anthropocentric what implies that the sovereignty belongs to the people.

Comments to the results of the study are of interest. First of all, they say that this situation with democracy is the result of circumstances: modern history, lack of experience, the legacy of the colonial era, as well as "old political culture". All this "promoted to the statement of political habitus of submission and rebellion" (Addi L., 2003).

It affirms that Islam as such is not a reason for preventing democracy establishment. L. Addy, an Arabist, writes (Addi Lauhari - a professor of sociology in Institute of Political Studies in Lion), "The Sacred Text offers the multiplicity of readings and it is able to justify both authoritarian and democratic regimes....Islam... is a discursive practice that advocates opposing camps use for the protection of their political positions " (Addi L., 2003).

Democratic vision regarding the political regime supposes freedom of thought and debate on all key issues of our time. Thus, C. Castoriadis (Castoriadis Cornelius $(1922-1997))$ states that the democracy corresponds to the "ability to internal protest, calls into question their own institutions and their ideas for the sake of reasonable discussion between people and this system is open and does not know some higher dogma". (Castoriadis C., 1996).

In democratic countries with the current political system, as the political practice indicates, there is no consensus on many issues of social development. Recent examples of "unanimity" could be observed only in the history of totalitarian, fascist countries in particular. In a democratic society it is common practice for a debate on the complex issues of social development, especially in cases where there is uncertainty in the understanding of a problem for which it is necessary to make decisions. This means that in any case in such discussions it is necessary to consider all the beliefs and values that guide the participants in the discussion. In a democratic society there are also exist activity areas within the debates are considered legitimate.

In the context of a consensus on the key issues of human existence it is impossible to find an objective, an adequate solution of the situation. Moreover, it is impossible to conduct a democratic discussion of the problem.

Let's take, for example, the issue of human rights. In the "Universal Islamic Declaration of Human Rights," says: "Given that Allah through his revelations in the Holy Qur'an and the Sunnah of their Prophet Muhammad gave mankind the right and morality, allowing to establish and regulate all the necessary institutions and relationships ... We Muslims believe in Allah, the Merciful, the Compassionate, the Creator, the Almighty, the Source of all laws and leading humanity on the right path ... believed in the destiny of man, which was created in order to fulfill God's will on earth (Khilafah) "(http://www.idmedina.ru/books/history_culture/minaret/16/declaracia-01.htm).

In the Universal Islamic Declaration of Human Rights in this regard, we find the following: "Rationality itself without illumination by God, can neither specify to mankind the only correct way or give spiritual nourishment the human soul; confident that the teachings of Islam represent the quintessence of Divine Providence in its final and perfect form, consider it their duty to remind a person about high purpose and dignity, that gave him the Most High "(http://www.idmedina.ru/books/history_culture/minaret/16/declaracia-01.htm).

The Declaration on Human Rights in Islam: "Everyone has the right to express their thoughts and beliefs to the extent and degree in what it is provided for by law" (http://www.idmedina.ru/books/history_culture/minaret/16/declaracia01.htm).

In most Arab countries, freedom of thought is a complex problem. Moreover, this freedom is pursued criminally. Examples of this are many in different Muslim countries. It is very difficult find its right to exist, and the principle of 
pluralism in Muslim countries. Without the rights of the opposition to express their views, as is known, there can be no talk of democracy. The emphasis on unity and distrust to pluralism are gaining strength precisely where arise democratic ideas. 'Democratic rights - wrote recently B. Stora (Stora Benjamin (b. 1950)) on the Arab Spring - are also in the perception of other words. It is necessary that the political parties embraced the idea that there exist another parties with other programs. An important rate for the Arab countries is the ability to perceive the plural "(Stora B., 2011).

Pluralism, which is consistent with Islam - is pluralism of traditional society, in which coexisting a plurality of communities, such as millets (Millet - initially a theological and juridical term in the Muslim countries - a religious creed with autonomous administrative establishments (trials, schools, hospitals, etc.) in especially allotted quarter or place of the town) in the Ottoman Empire, each of which is guided by their own rules, and led essentially divided existence. In the Qur'an, concerning such communities said: "They would like to see you were wrong, how wrong they were, and you would have turned out the same. Do not take of them friends until they were evicted by the way of Allah; But if they turn away, then grasps them and kill them wherever you find them. And do not take any of them friends or helpers "(Averroès., 1996)

This ideal of democracy based on consensus, can deceive, as stated M. Arkoun: "Yes: the consensus of the faithful. When I first discovered this idea, it prompted me to dream. I said to myself: Islam can realize democracy! In this case, what the Quran calls the ummah is a consensus. As a result, we can see a lot of Muslims, who are now convinced that yes, we have a democracy, thanks to the consensus of believers "(Animism (from Latin anima, animus - «soul» and «spirit») is a belief in the existence of soul, spirits and spirituality of the nature).

However, it would be wrong to underestimate the political changes that are caused in the Arab world, the Arab spring. As noted by S. Burg, there are "inclusions of democracy in Islam, but they are not enough to see them as a democratic regime itself, which cannot be reduced to the polls or the dictatorship of the majority" (Aoun S., 2013).

However, as it was pointed out at a conference in Brussels in October 2012 by Anwar Ibrahim, former Deputy Prime Minister of Malaysia, this does not in any way exclude the possibility of democratic development in Muslim countries. It would be wrong not to see the fact that India is the second largest Muslim country in the world, has established a democratic political regime. And that means that millions of Muslims, Hindus, observing the rules of the Quran and Sharia, live up to democracy. Another example: Indonesia, the largest Muslim country in the world, despite the relatively low level of economic development and the presence of a number of other difficult social problems, also develops towards democracy (Cf. «Printemps arabe», an II, quell devenir? 2013).

\section{The Prospects of Democracy in the Muslim World After the "Arab Spring"}

In the modern era a deep crisis are both traditional and "modernized" types of authoritarianism in the Middle East. Perseverance and "immobility" authoritarian order to emerging challenges are in fact an illusion. One of these challenges for the contemporary authoritarianism - the events, today called the "Arab spring." The Arab Spring is the revolutionary wave of demonstrations and protests in the Arab world which began December 18, 2010. There have been revolutions in Tunisia and Egypt; the civil war in Libya, which led to the fall of the regime; civil revolt in Bahrain, Syria and Yemen; mass protests in Algeria, Iraq, Jordan, Morocco and Oman; and less significant protests in Kuwait, Lebanon, Mauritania, Saudi Arabia, Sudan and Western Sahara. Clashes on the border of Israel in May 2011 also were inspired by the local "Arab Spring.". In many respects, the concept of "Arab revolution" is quite debatable, and scientists should not abuse it. In spite of the substantial change in the political landscape, it is still impossible to talk about systemic change in terms of transitological paradigm. Revolution in Tunisia also remains in question. The fall of the Gaddafi regime in Libya, with some degree of caution could be seen as a revolution, at the same time with unclear reasons. Similarly, in the case of Syria, we can talk about trying to implement similar within the meaning scenario, which is actively supported from outside the country.

To opinion of some researchers the situation in many states of the region is still uncertain and has no sign of imminent restoration of stability and makes many of the theoretical arguments about the "democratization of the Middle East" frankly speculative (Schluemberger O., 2012)

In the public mind in the meantime it confirmed the view that the Middle East due to the events of the "Arab Spring" stood on a steady path of democratization.

In this regard, a number of significant issues are inevitable. Is today the full potential of "authoritarian modernization" in the Middle East and the "Third World" exhausted as a whole, taking into account the effects of globalization and the "information network society"?

Do the prerequisites for the establishment in the countries of the "Third World" stable institutionalized democracy occur in this region of the world revolutions? And if not, what type of political order will be the result of authoritarian 
regime collapse in the region?

Events acquired high dynamics to make possible the changes of so a deep nature and scale which the region has not experienced over the last 50 years. To answer the question about the form of state in the Middle East after the "Arab spring" we should take into account the "political heterogeneity" of the region, which includes 20 countries - from the traditional monarchies, the Persian Gulf (Saudi Arabia led) to presidential regimes with a "socialist past" in the spirit of "Arab socialism" or "pan-Arabism" (Egypt, Syria, Algeria, to a certain degree Tunisia and the Republic of South Yemen in the early period of its political development) - to the states, for which we can talk about the existence of certain form of political domination with a high degree of conditionality, because they meet the criteria of a functioning statehood.

In this way it is reasonable to speak about "person's not general expression" for the States that make up this "world region". And as countries in the region are moving today through the unfinished transformation process, we can say about certain "intermediate results" "of the Arab Spring." One also should be aware of the following circumstances:

As today in many places - and not least in countries of the region themselves - talk about "Arab revolutions", the term should be used more cautiously.

And if you use preconceived concept of "revolution", it can be argued that Egypt really experienced "mass uprising", but not a revolution in the classical sense - because it preserved many essential elements of the Mubarak regime, and the main changes concerned only the structure of the elite. In the case of Tunisia "authenticity" of the revolution remains in doubt, too. With a certain caution the fall of the Gaddafi regime could be determined as a revolution with the "non-obvious" political result.

It is also should be considered carefully the events "of the Arab Spring" in the spirit of popularized concept of "democratization of the Arab world." For example, in Morocco there was a cosmetic reform of the Constitution that only relatively limited the power of the king Muhammad V. In Tunisia and Egypt today goes the reorganization of the political system in the direction of creating a "party landscape" of pluralistic type.

Tunisia gives the only example in the Arab world, which in the future could lead to democracy. In most cases, one can speak about transient conditions of "hybrid nature" with a greater or lesser degree of political pluralism.

At the same time the almost intact traditional "oil" Gulf monarchies (Saudi Arabia, Bahrain, Kuwait, UAE, Oman, Qatar), also faced in 2011 with the long mass protests.

The range of expected regime trends in the Middle East after the events of the "Arab spring":

1) Opened or closed military regime;

2) Monarchy adapted to the modern development process;

3) Parliamentary regime;

4) "Islamic democracy", where Islamic fundamentalist state would rather be the exception;

5) Traditional tribal state as a result of the collapse of the national states and diving into the chaos of a civil war (Kleinwaechter L., (2011)).

The results of "The Arab Spring" and wider process of modernization in the Arab East countries bring up the question about ability of the Muslim society for modernization.

In the 1990s it seemed that "the Asiatic miracle" and cultivating of "the Asiatic values" (striving for success provided high discipline and relatively weak individualism) were able to provide the modernization progress. But the economic crisis which has shaken Southeast Asia in the end of the 1990s ruined this euphoria. For the majority of the Asian societies it turned to be too hard to unite political democratization with economic development and economic liberalization.

The researchers are divided in their views concerning the possibility of including the Islamic states into the system of "neo-modern" capitalism. A distinguished American geostrategist S. Huntington felt dubious about such integration and preferred to talk about the approaching clash of civilization (Huntington Samuel.,1994). I. Wallerstein, in his turn, applying his World-System Theory considers "global anarchy" to be a long lasting period while the rivalry among the main global players will make the global development unpredictable (Wallerstein I., 2003). The opinion of Sh. Eisenstadt is less pessimistic when he talks about "the variety of modern civilizations" as about a possible and desirable perspective; it implies the existence of various modernization strategies and their spreading to the Islamic countries as well (Eisenstadt S. N., 1999).

The perspective ambiguity of modernization and democratization process in the Islamic states is confirmed by analysis of the internal political dynamics in Muslim societies. Today there is a situation when "Islam is no longer identical to Islam" (Metzger A., 2002) and inside the Muslim`s world the rivalry is evolving among three main Muslim projects Islamic fundamentalism, Islamic reformism and Islamic modernism. The fundamentalism is a type of reaction towards the dominance of the West in global development process. Founded upon the dogma of holy texts the fundamentalism acts against "systematic oppression of the Islamic nations` interests". 
Islamic reformism, in its turn is a movement emerged in the beginning of XX century aiming to provide Islamic countries an adequate position towards the West by the way of deep reformation of society and active technological adoption from the more developed countries.

Modernism is a movement supporting the democratic institutes legitimized by reference to Muslim norms and values treated in a modern way. It means the inculcation of such institutes into the public life in close connection with European ideas and opposition to the popularization of "Arab socialism" ideology (Elger R. (ed.)., 2001).

The main lesson is that the Arab nations demonstrated distinguished differences in interpretation of modern political development models.

The Lebanon and Jordan experience is comparatively successful and the achievements of Morocco give us hope. But the previous leaders of democratization, Tunisia and Egypt, made a step back. After the upheaval of "The Arab Spring" Egypt turned back to a traditional "military rule" aiming to preserve the modernization project and secular way of development.

The authoritarian tendencies became stronger in Turkey during Erdogan's period. It expressed itself in refusal from some postulates of Kemalism and reinforcement of "moderate Islamism" and "neo-osmanism" (Tanaskovich D.,2012).

Iran actively develops democratic institutes including free elections and civil rights notwithstanding the ambiguous legacy of the Islamic revolution.

The Muslim societies confront now with serious challenges. There is a glaring contradiction between political goals of the Islamic societies and fundamentalist influence from the sources beyond these countries and nations. Simultaneously the conflict evolves between "rentier state" acting on behalf of the narrow elite groups and the countries with traditional political models founded on the Muslim values (Elsenhans H. 2012)

The model of "rentier state" explains the well-being of such countries by their oil trade revenues what provide the ruling elites with a proper extent of independence from the internal political groups and social classes (Moaddel M., 2002). Lastly, the phenomenon of terrorism is another powerful conflict-wakening factor in the Islamic world. Among the stalwarts of terrorism we often see not social outcast but wealthy and well-educated people who consider their activity for the sake of the holy goals.

Thus, contemporary modernization theory regards the Islamic way towards the modern society as one of the possible developments with unpredictable results. The final perspective of democratization in the Arab countries depends upon the feasibility of their own version of modernization project.

\section{References}

A thorough analysis of the differences of Islam in Morocco and Indonesia is presented in the works of a well-known American anthropologist and sociologist Clifford Geertz (1926-2006), in particular in his work edited in 1968 in Chicago

Addi L.. Pluralisme politique et islam dans le monde arabe // Pouvoirs. № 104. 2003.

Addi Lauhari - a professor of sociology in Institute of Political Studies in Lion.

Adonis (the real name Ali Ahmad Said Asbar, b. 1930) - a Syrian poet and essayist. He was several times promoted to the Nobel Prize on literature.

Adonis. Printemps arabes. Réligiona et révolurion. P., 2014.

Agora - a central square in ancient Greek city-states, the place of all community rallies which also were called "agoras". There was placed the main city market and government buildings. Agoras often were encircled by galleries with craftsmen workshops, temples and sometimes statues. Agoras were often the administrative and economic center of the state. The acting laws engraved in stone and other official enactments were displayed in public on the agoras.

Al-Farabi ( 872 - between Dec. 14, 950 and Jan. 12, 951) - an Eastern philosopher, mathematician, theoretic of music, scientist. AlFarabi is the author of the comments on Aristotle's writings (he got an honorable nickname "The Second Teacher") and on Plato's.

Animism (from Latin anima, animus — «soul» and «spirit») is a belief in the existence of soul, spirits and spirituality of the nature.

Aoun S. Le printemps arabe, mirage ou virage? Entretien avec Stéphane Bürge. P., 2013.

Arcoun M. La construction humaine de l'islam. Entretien avec Rachide Benzine et Jean-Louis Schlegel. P., 2012.

Averroes (1126 - 1198) was a leading Arab philosopher, an influential representative of Aristotle`s ideas; tried to connect the doctrine of Aristotle with Islamic theology. According to Averroes's idea, there exists the only active intellect - the God1s mind which actualized the potential intellect. Averroes learnt about the eternity of the created world and monopsychism (there is the only intellectual soul general for all people. The emanation of God which is everlasting while the individual souls are mortal).

Averroès. Le Livre du Discours décisif. P., 1996.

Castoriadis C. La Montée de l'insignifiance. Les carrefours du labyrinth IV. P., 1996.

Castoriadis Cornelius (1922 - 1997) - a French philosopher, economist and psychoanalyst of Greek origin.

Cf. «Printemps arabe», an II, quell devenir? //Les Cahiers de l'Islam. Novembre 2013.

Cf. Geerz C. Islam Observed, Religious Development in Morocco and Indonesia. Chicago, 1968. 
Cf. Vernant J.-P. Les origins de la pensée grecque. P., 1962.

Corbin H. En islam iranien. Aspects spirituels et philosophiques. 1. Le chiisme duodecimaints. P., 1971. P 4.; Cf. Corbin H. Philosophie iranienne et Philosophie comparée. P., 1985. P 120.; Daryush Shayegan. Le Regard motilé. Schizophrénie cultirelle: pays traditionnels face à la modernité. P., 1989. P. 138.

Dervish (Pers. a beggar) is the Islamic analogue of a monk and ascetic, follower of Sufism.

Eisenstadt S. N. Multiple Modernities in an Age of Globalization // Grenzenlose Gesellschaft, Teil 1. Opladen: Leske \& Budrich. 1999.

Elger R. (ed.). Kleines Islam-Lexikon. Muenchen Beck, 2001.

Elsenhans H. Rentierstaat Algerien. Realität vs. konstruierte Wirklichkeit // WeltTrends. 2012 (3). Nr. 85.

Gabriel - an archangel mentioned in the Old and New Testament and Quran. Gabriel was a harbinger of God in the Bible and Quran. http://grani.roerich.com/plato/txt/republic05.htm

http://www.idmedina.ru/books/history_culture/minaret/16/declaracia-01.htm

Huntington Samuel. The Clashe of Civilization // Полис. 1994. № 1.

Iribarne Ph.d'. L'islam devant la démocratie. P., 2013.

Jambet Ch. Qu'est-ce que philosophie islamique? P., 2011.

Jambet Christian (b. 1949) - born in Algeria, a French philosopher and specialist on Islamic philosophy.

Jean Pierre Vernant (1914 - 2007) was a French historian and anthropologist.

Kabyle is a historic and geographic region in the northern part of Algeria. It partially covers the Atlas mountains and the Mediterranean cost.

Kemal Atatürk (1881 - 1938) is an Osmanic and Turkish reformer, politician, statesman, military leader; the founder and the first president of the Turkish Republic, the founder of the modern Turkish state.

Kleinwaechter L., Kraemer R. Der Aufstand von 1432 // WeltTrends Spezial. Ausgabe 1 (2011).

Leca J. La democratization dans le monde arabe: incertitude, vulnérabilité et légitimité // G. Salamé et al. Démocratie sans démocratie. Politique d'ouverture dans le monde arabe et islamique. P., 1994.

Manichaeism is a religious practice in the late antiquity created by a Persian prophet Mani or Manes.

Meryem Sebti. Philosophie islamique // M. A. Amir-Moezzi (dir.) Dictionnaire du Coran. P., 2007.

Metzger A. Die Vielen Gesihter des Islamismus // Aus Politik und Zeitgeschichte. B 3-4/2002.

Millet - initially a theological and juridical term in the Muslim countries - a religious creed with autonomous administrative establishments (trials, schools, hospitals, etc.) in especially allotted quarter or place of the town. In XV-XX centuries the term was popular in the Ottoman Empire for classification of its peoples by religion.

Moaddel M. The Study of Islamic Culture and Politics: An Overview and Assessment // Annual Review of Sociology (28). 2002.

Mohammed Arkoun (b. 1928) a well-known Islamic intellectual, a professor of Sorbonne since 1970.

Providentialism (from Latin providentia - providence) is a historic and philosophic method of researching the historic events from the point that Providence is present in such occurrences and that God has the beforehand plan of saving people.

Revelation - declaration of God's will according to the Christian dogmas.

Schluemberger O. Nach dem arabischen Fruehling // Welttrends. 2012. N 82.

Shamanism is a previous form of religion based on the belief that shaman communicate with spirits when being in trance. Shamanism is connected with magic, animism, fetishism and totemism.

Stora B. Le grand enjeu des pays arabes est d'admettre la pluralité // Libération. 25 novembre. 2011.

Stora Benjamin (b. 1950) - a French historian, specialist on North Africa, one of the leading world specialist on history of Algeria.

Tanaskovich D. Turkey and the Balkans: Old traditions, new Aspirations // Israel Journal Foreign Affairs. 2012. № 6.

Vaner S. Passage de la laîceté jacobine à la sécularité laîque en Turquie? // Vaner S., Yeradsveit D., Kazancigil A. (dir.) Sécularisation et démocratisation dans les sociétés musulmanes. Bruxelle, 2008.

Vaner Semih $(1945$ - 2008) - French geopolitician of Turkish origin, the president of the French Association of East Mediterranian Studies and Turkic- Iranian world

Vernant J.-P. Les origins de la pensée grecque. P., 1962.

Wallerstein I. Entering Global Anarchy // New Left Review. (22) 2003.

Weber M. Économie et société. En 2 vol. P., 1995. Vol. II.

Zoroastrianism is a form of religion in the ancient ages and early Medieval ages in the Middle Asia, Persia, Afghanistan, Azerbaijan and some countries in the Near and Middle East; is still observed by the Parsi in India and Gebri in Iran. The name is derived from the name of the prophet Zoroastra (Zaratushtra). The main principles of Zoroastrianism: contraposition of the two everlasting commands - the good and evil; the struggle between them is the core of the world's being; the belief in the victory of the good personified by the supreme godhood Ahura Mazda. The fire plays the main role in Zoroastrianism.

Аристотель. Сочинения в 4 т. М., 1984. T. 4. (Aristotle. Writings in 4 volumes, Moscow, 1984, V.4)

Коран M., 1963 (Quran, Moscow, 1963) 